\title{
Implementing Ecologically Based Invasive Plant Management: Lessons From a Century of Demonstration Projects in Park Valley, Utah
}

\section{By Lesley R. Morris, Thomas A. Monaco, Christopher A. Call, Roger L. Sheley, and Michael Ralphs}

$\mathrm{H}$ istory is repeating itself in Park Valley, Utah. Land-use history in this sagebrush rangeland north of the Great Salt Lake reveals a long tradition of using demonstration sites to encourage agricultural improvement (Fig. 1). The first demonstration site was established in 1911 by the Pacific Land and Water Company as an experimental farm to display and promote the practice of dry farming (agriculture without irrigation). ${ }^{1}$ The second was a cooperative demonstration ranch formed by local landowners and the Utah Rangeland Development Program in 1974. ${ }^{2}$ This effort sought to demonstrate how livestock management practices and range improvements increased forage production. The most recent demonstration sites were established in 2008 for a multistate, area-wide project to research and demonstrate "Ecologically Based Invasive Plant Management" strategies for rangelands impacted by invasive annual grasses. ${ }^{3}$ Ironically, demonstration efforts now have come full circle from showcasing dry farming to showcasing options to remediate a persistent ecological impact of the dry-farming boom-the invasion of cheatgrass (Bromus tectorum). ${ }^{4}$ This article explores historical aspects of these demonstration projects and the lessons about how their outcomes assist with implementing an Ecologically Based Invasive Plant Management program. Although the number of demonstration sites might be unique to Park Valley, the land-use history and changes it has experienced are commonplace throughout the West. This historical legacy and its lessons have important implications for management objectives across the West.

\section{Pacific Land and Water Company Demonstration Farm}

"Own a home in Park Valley, and buy it now. It is not a time for waiting. The great American people-men, women and children in every walk of life-are land bungry." Pacific Land and Water Company. ${ }^{1}$

The push and pull of settlement in the West had not yet been satisfied in America by the turn of the 20th century. States wanted to increase their populations, the federal government sought to dispose of the public domain, and the railroads, with associated land companies, wanted to sell off the last railroad land grants for profit. ${ }^{5}$ The effort to complete the first transcontinental railroad in the United States included an arrangement of land grants to the railroads for them to sell to finance this great endeavor, creating a "checkerboard" of land ownership along railroad corridors (Fig. 2). ${ }^{6}$ The first lands to be sold were sections in areas suitable for timber harvest, mineral extraction, and farming; the most arid lands (e.g., across northern Nevada and Utah) were some of the last to be sold. Therefore, in the early 1910s, the federal government and the railroads were still promoting settlement in the arid west. ${ }^{5-7}$ The Jeffersonian vision of the farmer-settler and importance of agricultural development of land was still very prominent in America.

In the arid and semiarid areas of the West, where irrigation agriculture was not feasible, many believed that dry farming could reclaim this American ideal. Dry farming essentially is agriculture without the use of irrigation. It was, of course, not a new practice, but one with a history as old as the ancient Egyptians. ${ }^{7}$ However, in 1900, H. W. Campbell 


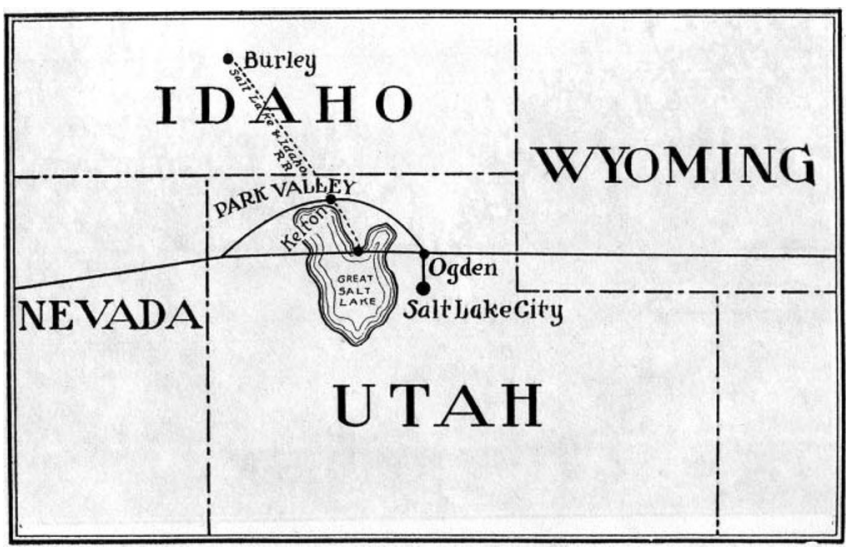

Figure 1. Location of Park Valley, Utah, as pictured in a Pacific Land and Water Company flier, 1911. Photo courtesy of Utah State Historical Society.

redeveloped and adapted the method. His famous revisions created a system of planting one area on the farm, while deep plowing and leaving fallow another area to "store" moisture for the next year. ${ }^{7}$ The growing interest in dry farming, along with the appeal of the new Enlarged Homestead Act of 1909 and clever promotion by land companies in the region, resulted in a rush of new claims and development in the Great Basin. ${ }^{5-7}$ Park Valley was no exception. Its "land boom" started around 1910 with hundreds of people immigrating to attempt dry farming. ${ }^{8}$
Land in Park Valley could be obtained in several ways: through homesteading, direct purchase from the railroad, or through land companies. One of the land companies offering sales in Park Valley, the Pacific Land and Water Company (PLWC), had over 12,000 acres to offer in 1911 (Fig. 2), and up to 180,000 acres by $1914 .^{1,9}$ The company used both ongoing research in "this new land science" of dry farming at universities, as well as boisterous claims regarding the potential for agriculture in the pamphlets they circulated to sell land in Park Valley.

"So important has become the subject of agriculture, that the leading universities and colleges of the country are specializing it in their courses. Utah has its own Agricultural College."

"Scientific dry farming is changing the dreary sage brush tracts into rich, prolific wheat fields, increasing the land's productiveness from 50 to 100 per cent at the lowest imaginable cost."

It was the "shrewdly contrived education or propaganda work" of the railroads and land companies that widely publicized dry farming. ${ }^{5}$ Demonstration tree farms and the establishment of wells helped promote land settlement near the railroads in the arid reaches of California. ${ }^{6}$ The PLWC surely must have followed this very model in setting up their demonstration farm in Park Valley.

"As evidence of its faith, the company has begun the development of a large tract of land, planting several thousand fruit trees and also grains, knowing from the evidence

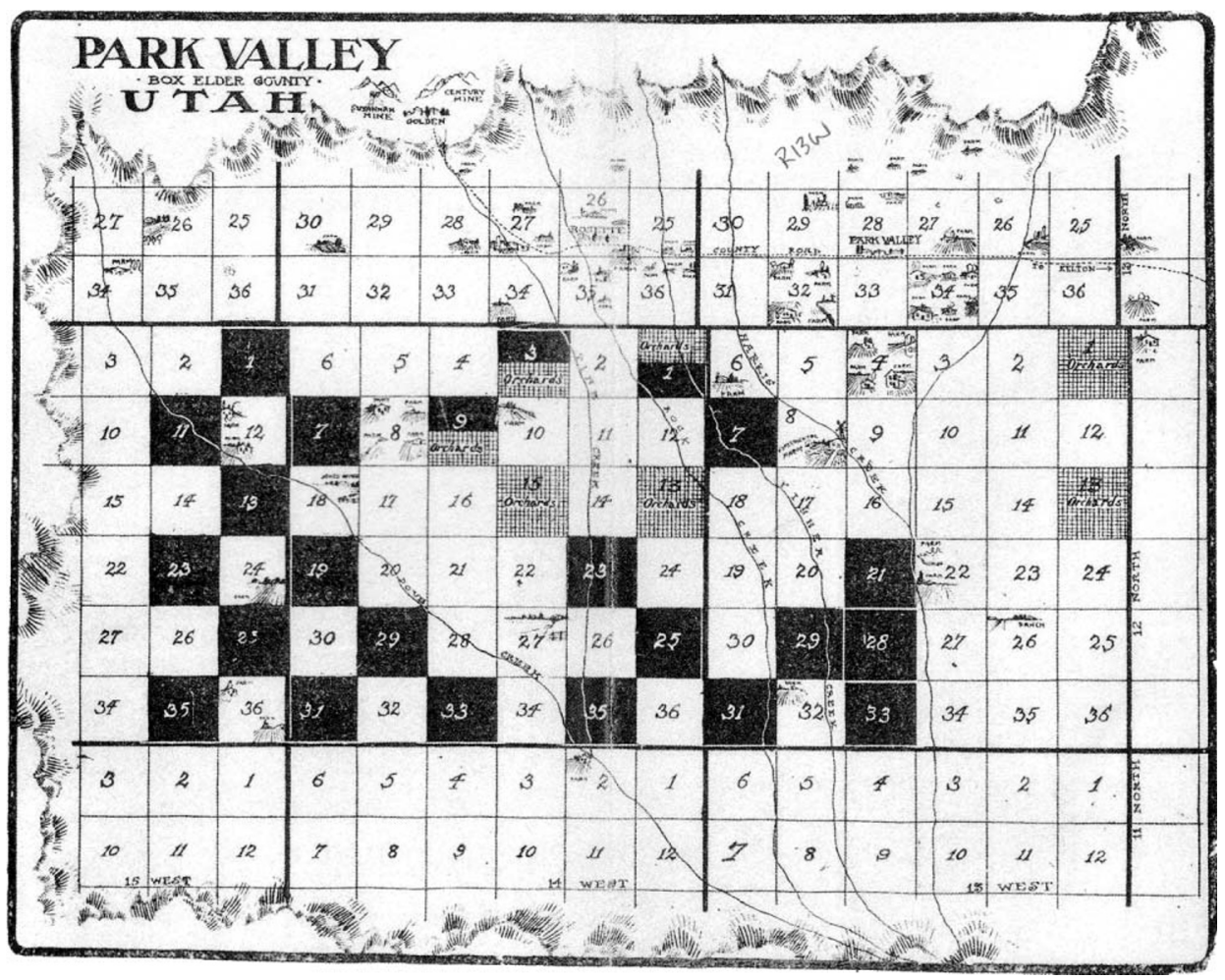

Figure 2. Land acquired from the railroad and offered for sale by Pacific Land and Water Company in Park Valley, Utah, in their company flier. This history of land sales created similar "checkerboard" patterns of land ownership across the West. Photo courtesy of Utah State Historical Society. 


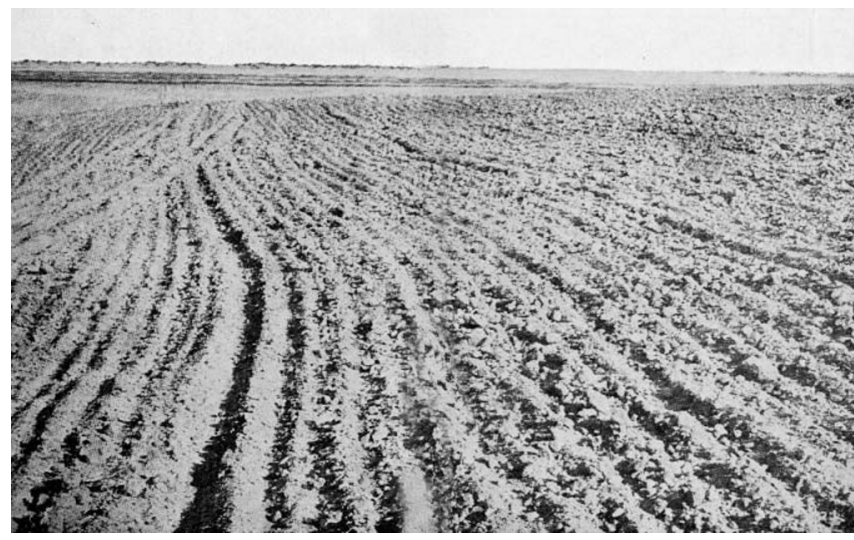

Figure 3. Demonstration Dry Farm in Park Valley, Utah, 1911. Photo courtesy of Utah State Historical Society.

abounding on every hand that it can make no greater profit than by such purchase and planting. It keeps a force of men and teams working the land continually the year round. What is good business for the company is good business for you."

In fact, the demonstration farm (Fig. 3) was not on land owned by the PLWC, but on a quarter section (160 acres) owned by Edmund F. Barlow who worked for the company as a consultant to demonstrate how to dry farm. ${ }^{9}$

Across the arid West, many of the places promoted by land companies turned out to be marginal lands with inhospitable climates for agriculture and settlement. ${ }^{10}$ Unfortunately, dry farming was not well suited to Park Valley's soils and climate, and for some, it was a complete disaster. The story of a group of Russian immigrants who were persuaded by the PLWC promises gives an example of the 'gulfs between boosters' and settlers' expectations and actual outcomes."10 Lured into purchasing $4 \mathrm{mi}^{2}$ of greasewood-covered land from the PLWC, fifteen families put everything they owned into farming in Park Valley. ${ }^{11}$ Over a short period beginning in 1914, they experienced extreme hardships, disappointment, and eventual failure at homesteading within this arid landscape. This community of Russians mostly focused on cultivating small garden plots and grain, but also attempted to dry farm on about 80 acres. Drought, dust storms, and cloudbursts were all blamed for continuing difficulty in farming. By 1916, the Park Valley scheme was beginning to collapse, and even Edmund Barlow moved to an area near the city of Provo, Utah. ${ }^{11}$ The last Russian family left by $1917 .{ }^{9}$

The abandoned fields left behind by these and other hopeful farmers were fertile ground for exotic annual plant species, such as cheatgrass, halogeton (Halogeton glomeratus), and Russian thistle (Salsola sp.). Cheatgrass, the weed named for cheating the farmer out of a good crop of dry-land wheat, was particularly well-suited to colonize these disturbed areas. ${ }^{4}$ Once established, cheatgrass and other exotic-plant dominance can persist for decades. Although no dry farming occurs in Park Valley today, the scars of the plow and the invasive annuals remain as a legacy.

\section{Park Valley Hereford Corporation Demonstration Ranch}

"What a man hears, he may doubt; what he sees, he may also doubt; but what he does, he cannot doubt." Seaman A. Knapp (founder of Cooperative Extension Service).

In 1974, a local "improvement association" organized in Park Valley and approached the Bear River Association of Governments for assistance through the Resource Conservation and Development (RC\&D) Program. Their project was funded through the Utah Rangeland Development Program by the Four Corners Regional Commission and the Extension Service, whose objective was "accelerating development of Utah's rangelands." At the time, the Park Valley Hereford Corporation (PVHC) was an association of eight ranchers controlling about 15,000 acres of private lands and grazing permits on lands managed by the Bureau of Land Management and the state of Utah. ${ }^{2}$ It was selected for the demonstration ranch because there was good potential for success, it was centrally located and highly visible to the community, and it involved all the federal and state agencies as well as private property owners. In addition, several of the shareholders were "vocal proponents of change."

Years of heavy livestock grazing and fire exclusion were blamed for the increase in sagebrush cover, reduction of nutritious forage grasses, and the encroachment of pinyonjuniper woodlands onto the corporation's grazing lands. ${ }^{2}$ Cooperators on this project included: Bureau of Land Management (BLM); Soil Conservation Service (SCS, now the Natural Resource Conservation Service); US Forest Service; Utah Division of Wildlife Resources; Utah Division of Forestry and Fire Control; Agricultural Stabilization and Conservation Service; West Box Elder Soil Conservation District; Bear River RC\&D; Utah State University Extension Service; and the property owners associated with the PVHC. A primary concern at the time was that with so many agencies and people involved, the effort would be stalled. ${ }^{2}$ One rancher stood in a planning meeting in July of 1974 and lamented that if "all of these planning processes were to be completed, he would not live long enough to see the end result."

The project required an updated SCS conservation plan, a detailed range site condition and production survey, improvement and management alternatives in a management plan, environmental impact statements for the BLM and the Division of Wildlife Resources, a burning plan, and a burn permit. Still, the project moved ahead very quickly. It took 45 days to complete all the required documents to move forward with the demonstration project. The level of cooperation and resources that were extended by all the agencies surprised everyone. That fall, 800 acres of land were burned and seeded with the drought- and grazing-tolerant forage species, crested wheatgrass (Agropyron desertorum)., ${ }^{2,12}$ Unfortunately, some of the momentum and good feelings were compromised that winter when the typical snow cover 


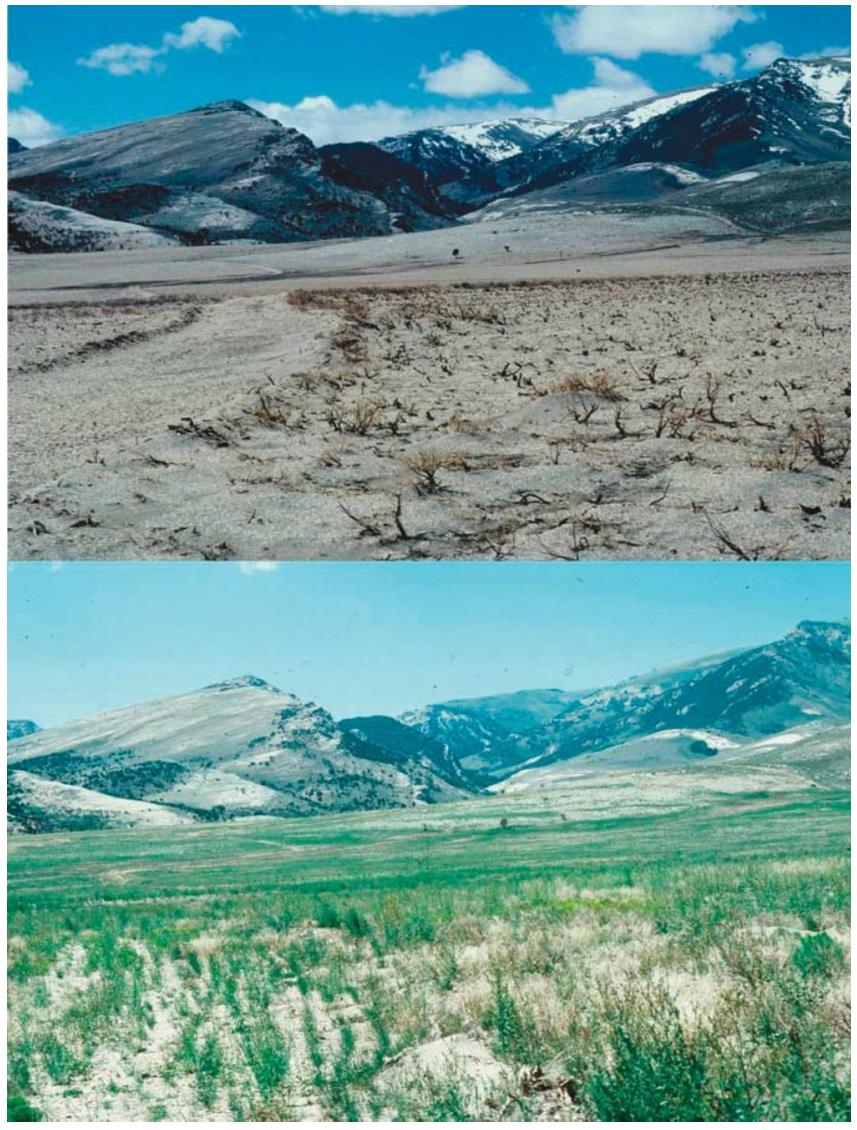

Figure 4. The typical snow cover in Park Valley did not protect fireexposed soil after treatment on the Park Valley Hereford Corporation (PVHC) demonstration ranch, but the stand of grasses the next spring helped stabilize the soil surface and community tensions over the dust and soot. Photos by Michael Ralphs.

did not protect the fire-exposed soil from wind erosion. Many in the community were unhappy with the dust and soot that blew through the valley. However, by the spring, a nice stand of grass helped dissolve any hard feelings (Fig. 4).

Building upon their success from that first year, the demonstration ranch collaborators treated (burned, sprayed or chained, and seeded) 6,000 acres, and installed new water developments and fences over the next five years (Fig. 5). By 1982, 30 of the 40 ranches in the community had participated in "some kind of brush control," which meant at least 20,259 acres were cleared, burned, sprayed, plowed, or chained, and seeded. The level of participation speaks to how successful this demonstration ranch was at cooperatively improving rangeland condition and forage potential.

\section{Ecologically Based Invasive Plant Management (EBIPM) Demonstration Sites}

"Revegetation can be most successful when it works with successional processes to direct plant communities toward a desired state." Roger Sheley

\section{Acres Treated in Park Valley}

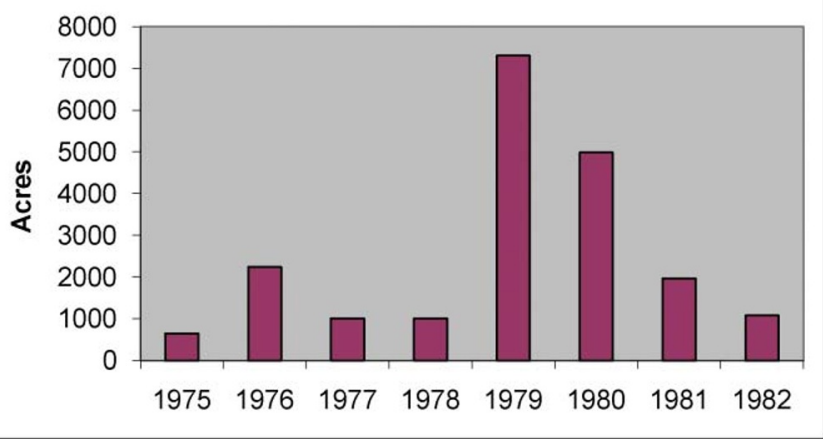

Figure 5. Acres treated in Park Valley after the Park Valley Hereford Corporation demonstration ranch project in 1974. Data by Michael Ralphs.

The latest demonstration project in Park Valley was initiated by the Agricultural Research Service (ARS), the primary research arm of the US Department of Agriculture. This area-wide EBIPM project aims to promote "sciencebased solutions for invasive annual grasses." ${ }^{3}$ In 2008, local ranchers, the ARS, the Natural Resources Conservation Service (NRCS), Box Elder County Extension, the Utah Association of Conservation Districts, and Utah State University teamed up to demonstrate the effectiveness of EBIPM principles at large scales. These ecological principles are based upon a successional management framework that relates the three primary causes of succession, which include site availability, species availability, and species performance to modify and to reduce invasive annual grass dominance and promote the transition of lands toward desirable perennial communities. ${ }^{13}$

The partnership was made official in the summer of 2008 , following numerous visits to cheatgrass-infested areas. The region has experienced four fires between the late 1980s and 2004, and has been moderately grazed in early spring and late fall over the past 30 years. Recent wildfires have shifted these sites from historical dominance by shrubs, perennial grasses, and forbs to dominance by cheatgrass and other annual plants. Touring throughout Park Valley and viewing rehabilitation successes and failures associated with the recent wildfires provided the ideal situation for the partnership to integrate local knowledge and experience with the EBIPM principles. A few observations emerged: 1) seeding drought- and grazing-tolerant grasses shows the most promise for successful establishment; 2) over time, these competitive grasses reduce cheatgrass abundance; and 3) herbicide application and seeding immediately after fires greatly improve cheatgrass control and seeding success. These observations then became the driving force behind the choice of treatments to explore for the demonstration areas. Plans were made to design large-scale experiments (120 and 240 acres) to replicate the underlying conditions of observed successes. 


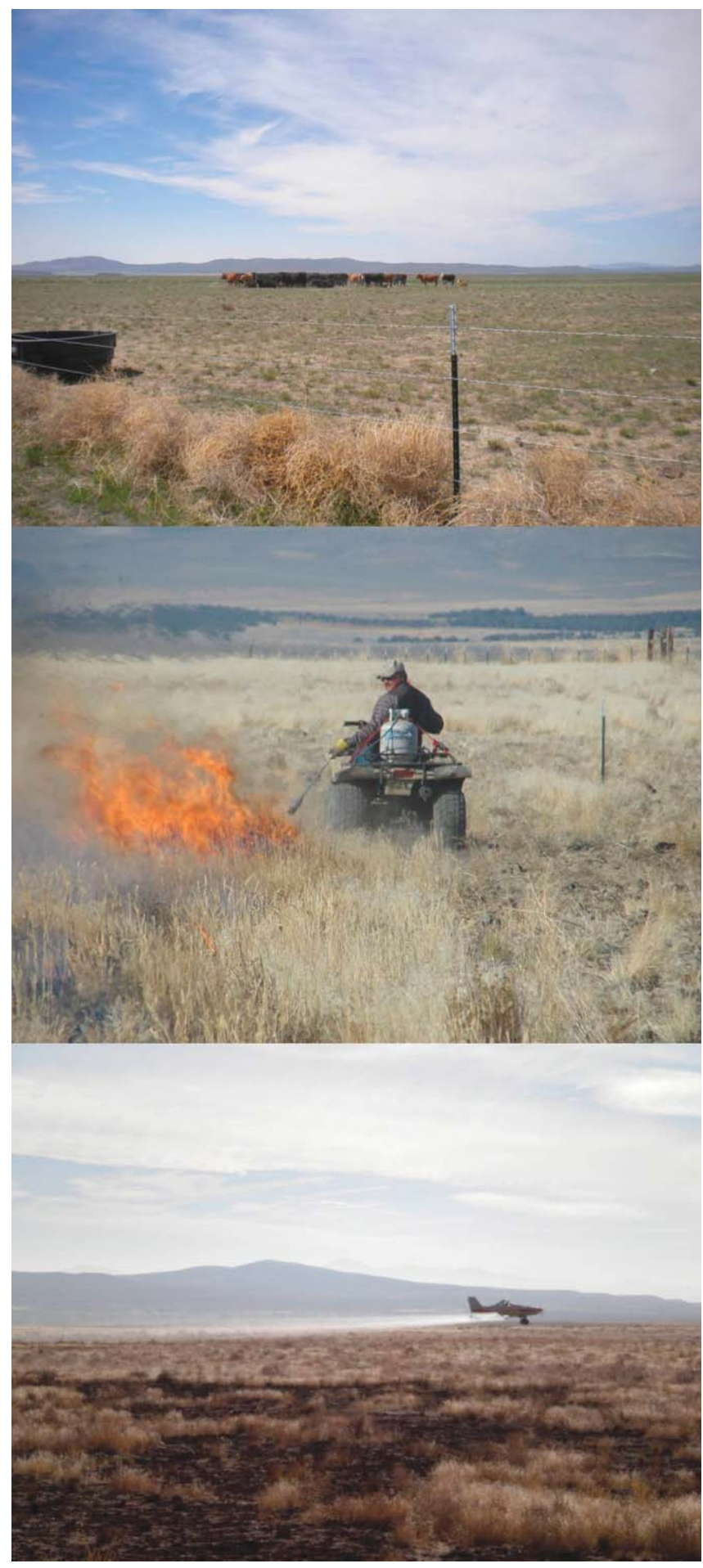

Figure 6. Successional management of the Ecologically Based Invasive Plant Management (EBIPM) demonstration areas including: targeted grazing (top), prescribed fire (center), and pre-emergence herbicide application (bottom).

In brief, the partnership agreed to prepare demonstration sites for using targeted early-spring cattle grazing to decrease cheatgrass biomass (species performance) and seed production (species availability), prescribed fire to decrease cheatgrass litter (site availability for germination), and pre-emergence herbicide to decrease cheatgrass seedling emergence (species performance) (Fig. 6). The underlying premise for this approach was that the sequence of grazing, burning, and herbicide treatments systematically impact the life cycle of cheatgrass and promote parallel improvements for species availability, site availability and species performance of seeded desirable species. It also was anticipated that establishing a functionally diverse community, resistant to weed invasion and repeated wildfires, requires redirecting the underlying causes of succession, instead of treating symptoms of the problem.

Targeted cattle grazing, prescribed fire, and herbicide treatments are being evaluated separately and in combinations to yield eight overall treatments. Intensive targeted grazing was implemented in spring 2009 by the partnering ranchers, and prescribed burning was conducted in October 2009 with the assistance of the Park Valley and Box Elder Fire authorities. The pre-emergence herbicide imazapic (trade names Plateau ${ }^{\circledR}$ or Panoramic $\left.{ }^{\circledR}\right)^{\mathrm{i}}$ was applied aerially prior to seeding the demonstration sites with a diverse mix of perennial grasses and forbs. Two Utah State University graduate students and their advisors were charged to oversee three main aspects of the research: 1) establish the effectiveness of EBIPM principles to reduce cheatgrass abundance and assist desirable species establishment, 2) quantify soil and vegetation heterogeneity across the demonstration area, and 3) determine the impact of rehabilitation efforts on soil properties. By addressing these overarching objectives, the partnership will identify the underlying processes responsible for success, and disseminate this information to local producers and land managers.

\section{Lessons from a Century of Demonstration}

Looking back over the last century of demonstration activities in Park Valley, we see at least three interconnected lessons for implementing demonstration projects for effective management of invasive annual grass-dominated landscapes such as ours-the importance of land-use history, community involvement, and realistic expectations.

\section{The Importance of Land-Use History}

The land-use history of homesteads, railroads, and land companies is more than just an interesting western narrative; it is the genesis of our present land management issues in the western United States. Dry farming was one of the primary sources for cheatgrass invasion and the disturbance from cultivation operated as an ecosystem driver toward a new successional trajectory for these rangelands. Several studies have shown the influence of land-use history on the long-term success of restoration efforts and the need to identify what brought these lands to the state of degradation

'Mention of a trademark, proprietary product, or vendor does not constitute an endorsement, guarantee, or warranty of the product by the USDA or Utah State University. 
in the first place. ${ }^{14,15}$ The aim of the current EBIPM project is to evaluate the long-term effects of dry farming (legacy effects) and incorporate land-use history into site assessments. For example, current research into the legacy of dry farming shows that it impacts vegetation in abandoned fields for nearly a century. ${ }^{16}$ Therefore, a site history for each of the EBIPM demonstration areas has been conducted to ensure that research results are not confounded by past landuse effects. Instead, site history can be incorporated properly with management by recognizing when lands have crossed ecological thresholds into an alternative state due to historic cultivation.

This land-use history also has left us with a checkerboard pattern of land ownership that makes continuity of management extremely difficult. The discontinuous spatial pattern of land tenure has been identified as one of the motivational constraints for livestock producers to implement change on their property. ${ }^{17}$ The spread of cheatgrass and accompanying increases in wildfire frequency do not respect ownership boundaries. In order for revegetation and rehabilitation efforts to be successful, land-use history must not be ignored, but rather legacy effects should be acknowledged and integrated into management decisions.

Increasing collaboration across the various land ownerships is one way to overcome the barrier of isolation in management innovation. The PVHC did this extremely well by bringing together all property ownership groups within the corporation. Having all the agencies in collaboration for the PVHC demonstration seemed like an amazing accomplishment-and it was! For better or worse, this dynamic even was at play during the dry-farming land boom when all of the land owners (land companies, federal, and state) were in support of the movement. Similarly, the current EBIPM project strives to involve private, state and federal stakeholders to transcend land ownership and coordinate efforts.

\section{The Importance of Community Involvement}

In order for any demonstration project to be effective in a community, it must involve the local people and their private lands. ${ }^{18}$ Even the dryland-farming promoters realized that using private property was the best way to "demonstrate" the effectiveness of the farm because private property owners were working every day to sustain their land and livelihood. In the case of the PVHC demonstration ranch, it was the local property owners who initiated the call for collaboration. Their success, more than just agency collaboration, stemmed from strong community support and involvement. Similarly, the current demonstration partners, as with the PVHC, also are "vocal proponents of change." They are full-time livestock producers, with multiple generations in the business, who live on the land they manage. This is important because research shows that all of these characteristics make them more likely to innovate and adopt new management practices. ${ }^{17}$ Surveys show that most ranchers get their information from family and other producers; ${ }^{18}$ likewise, the EBIPM project is counting on dissemination of management outcomes through word of mouth. However, surveys also show that livestock producers who consult a wider community, including experts from the extension agencies, are more likely to adopt new practices. ${ }^{18}$ The EBIPM partners already have been working closely with the agency collaborators.

In the EBIPM project, we are striving to involve and collaborate with many of the community members using the demonstration areas as a solid foundation for education and outreach. The first outreach effort was through a field visit to the demonstration areas as part of the bi-annual Box Elder County Conservation District tour in the summer of 2009 with nearly 50 producers in attendance. To follow up, an article highlighting research efforts of the project was included in the Conservation District's Fall 2009 newsletter along with a community presentation on dry-farming legacies. These outreach efforts led to two additional partnerships with private property owners in Park Valley to demonstrate EBIPM principles. May 2010 was the first opportunity to showcase some treatment results to a group of 60 land managers, researchers, and local ranchers during a field trip associated with the 16th Wildland Shrub Symposium in Logan, Utah. Future plans include regular Conservation District newsletter articles, showcasing outcomes and lessons learned from the demonstration areas. Therefore, in collaboration with the federal, state, and county personnel within the Box Elder Conservation District, and through word of mouth in the community, we have been striving to involve and report to as many people as possible about the EBIPM demonstration areas.

\section{The Importance of Realistic Expectations}

Although the Pacific Land and Water Company created outrageous expectations, their motivation was clearly an economic one-sell more land and make more money. But even without directly misleading the public, there is a potential for catastrophic disappointment if everyone involved is not fully informed of the benefits and the risks. ${ }^{19}$ Revegetation work in arid landscapes involves high risk of failure and unforeseen consequences. The PVHC group did not expect record low snowfall to contribute to dust and soot problems for the community. Luckily, when the grass came up it solved their problem.

Today, restoration managers are encouraged to start with "making a goal statement" or "developing preliminary repair objectives." ${ }^{20,21}$ But that might be easier than it sounds when working with collaborators with different views of the endpoint. Thus, it is more important than ever to set realistic expectations and to communicate about the possibility of not meeting them. Furthermore, in lesson one, we learned that historic land uses in Park Valley, such as dry-farming legacies, definitely influence what vegetation will grow there today. Therefore, to set a realistic expectation about revegetation goals, it is important to start with a thorough site 
assessment of what has happened in the past. ${ }^{15}$ Incorporating the lessons learned from the past is one way the EBIPM program communicates realistic expectations about the management outcomes.

It also is important to have realistic expectations regarding the amount of work, and the long-term benefits of a proposed revegetation plan. ${ }^{15}$ In fact, the idea of reducing cheatgrass was not necessarily well understood when the EBIPM project began in Park Valley. Many of the producers do not necessarily view cheatgrass as a problem. In Park Valley, it is locally known as "June grass" and is utilized as abundant (although unreliable) early spring forage. However, producers that were faced with recurring fires, annual grassdominated rangelands, and the extremely unpredictable forage that follows, were some of the first in the valley to be interested in improving their land. Admittedly, the ranchers were reluctant to eradicate cheatgrass unless rehabilitation efforts would include future grazing in the spring and lead to a more stable and consistent forage base. There was no disruption of their operations in 2009 because their animals were able to graze on the demonstration areas. However, grazing will be deferred from the demonstration sites during 2010 and 2011 to allow establishment of the seeded species. Everyone involved understands that if the seedings are successful, they should have access to greater, more dependable forage after 2012.

For most ranchers, "seeing is believing." 18 The PVHC understood this, and integrated it into its program almost flawlessly. The hard work from their demonstration ranch actually might have laid the foundation for the EBIPM project. This community of livestock producers already is accustomed to implementing techniques on the ground, assessing their successes and failures, and adapting to them. The EBIPM project does not require unique, untested, and unfamiliar practices. Instead, it applies familiar management techniques (e.g., targeted grazing, herbicide application, and seeding) in a way that is intended systematically to direct succession on the landscape. Although results from the demonstrations areas are preliminary after only one year, early feedback will be very important for partners to see right away.

\section{Conclusion}

"Those who do not understand history are doomed to repeat it." George Santayana

Repeating history will not doom us to fail, but not learning from it will. We have been repeating demonstration activities in Park Valley for a century now. This repetition imparts valuable lessons, through both the successes and failures, about the importance of history, community involvement, and realistic expectations. These lessons have been incorporated into the current demonstrations and research efforts of the EBIPM project. In addition, we believe these lessons from a century of demonstrations in Park Valley offer relevant guidance for rangeland restoration efforts across the West.

\section{Acknowledgments}

We wish to thank the community of Park Valley, Utah, and all of our area-wide EBIPM partners there. Specifically, we appreciate the cooperation of our demonstration partners, Ken Spackman, Royce Larsen, and Lance Westmoreland. We also want to thank "Fee" Busby for sharing his memories of the Park Valley Hereford Corporation Demonstration Ranch with us and for reviewing an earlier draft of this paper. Marshall Bowen was an amazing resource for the history of dry farming and land companies in the valley. Beth Fowers provided the grazing photo for Figure 6 and Josh Kunzler improved the quality of the image in Figure 2.

\section{References}

1. Pacific Land and Water Company. 1911. Invest dimes and reap dollars in Park Valley, Utah. Pamphlet (PAM 1723), Utah State Historical Society. 20 p.

2. Ralphs, M. H., and F. E. Busby. 1978. A project that made a second spring for Park Valley. Rangeman's Journal 5:86-88.

3. Sheley, R., E. Vasquez, J. James, and B. Smith. 2009. Applying ecologically based invasive plant management: an introduction and overview. Available at: http://www.ebipm.org/ content/5725. Accessed 29 July 2010.

4. Mack, R. N. 1984. Invasion of Bromus tectorum L. into Western North America: an ecological chronicle. Agro-Ecosystems 7: $145-165$.

5. Gates, P. W. 1968. History of public land law development. Public Land Law Review Commission. Washington, DC, USA: Government Printing Office. 828 p.

6. Orsi, R. J. 2005. Sunset Limited: The Southern Pacific Railroad and the development of the American West 1850-1930. Berkeley, CA, USA: University of California Press. 615 p.

7. Peffer, E. L. 1972. The closing of the public domain: disposal and reservation policies 1900-50. New York, NY, USA: Arno Press. 372 p.

8. Carter, N. K., L. W. Palmer, and D. K. Morris. 1970. Our one hundred years: 1870-1970. Utah State University Special Collections. Park Valley, UT, USA: Author. 49 p.

9. Bowen, M. E. 2003. Russian pioneers in the Utah desert: understanding a landscape of abandonment. Material Culture 35:9-20.

10. Wrobel, D. M. 2002. Promised lands: promotion, memory, and the creation of the American West. Lawrence, KS, USA: University Press of Kansas. 322 p.

11. Bowen, M. E. 2006. Two Russian Molokan agricultural villages in the Intermountain West. Yearbook of the Association of Pacific Coast Geographers 68:53-78.

12. Ralphs, M. H., and F. E. Busby. 1979. Prescribed burning: vegetative change, forage production, cost and returns on six demonstration burns in Utah. Journal of Range Management 32:267-270.

13. James, J. J., B. S. Smith, E. A. Vasquez, And R. L. Sheley. 2010. Principles for ecologically based invasive plant management. Invasive Plant Science and Management 3:229-239.

14. Kettle, W. E., P. M. Rich, K. Kindscher, G. L. Pittman, AND P. Fu. 2000. Land-use history in ecosystem restoration: 
a 40-year study in the prairie-forest ecotone. Restoration Ecology 8:307-317.

15. Новвs, R. J., And D. A. Norton. 2006. Towards a conceptual framework for restoration ecology. Restoration Ecology 4:93-100.

16. Morris, L. R., T. A. Monaco, and R. L. Sheley. 2011. Land-use legacies and vegetation recovery 90 years after cultivation in Great Basin sagebrush ecosystems. Rangeland Ecology \& Management in press.

17. Didier, E. A., And M. W. Brunson. 2004. Adoption of range management innovations by Utah ranchers. Journal of Range Management 57:330-336.

18. Kennedy, C. A., And M. W. Brunson. 2007. Creating a culture of innovation in ranching: a study of outreach and cooperation in west-central Colorado. Rangelands 29:35-40.

19. Tunstall, S. M., E. C. Penning-Roswell, S. M. Tapsell, AND S. E. Eden. 2000. River restoration: public attitudes and expectations. Journal of the Chartered Institution of Water and Environmental Management 14:363-370.

20. Krueger-Mangold, J. M., R. L. Sheley, and T. J. Svejcar 2006. Toward ecologically-based invasive plant management on rangeland. Weed Science 54:597-605.
21. Whisenant, S. G. 1999. Repairing damaged wildlands: a process-orientated, landscape-scale approach. Cambridge, UK: Cambridge University Press. 312 p.

Authors are Research Associate (Morris) and Rangeland Weed Ecologist (Monaco), USDA-Agricultural Research Service, Forage and Range Research Laboratory, 696 North and 1100 East, Logan, UT 84322-6300, USA, LesleyRMorris@gmail.com; Professor, Wildland Resources Department, Utah State University, Logan, UT 84322-5230, USA (Call); Rangeland Weed Ecologist, USDA-Agricultural Research Service, Range and Forage Meadow Management Unit, Burns, OR 97720, USA (Sheley); and Research Rangeland Management Specialist, USDAAgricultural Research Service, Poisonous Plant Laboratory, Logan, UT 84341, USA (Ralphs). The research discussed in this paper is funded through the Agricultural Research Service Area-wide Ecologically Based Invasive Plant Management Project. 